\title{
PENGARUH MODEL PEMBELAJARAN THINK TALK WRITE TERHADAP KEMAMPUAN KOMUNIKASI MATEMATIS SISWA KELAS X SMK SWASTA NAPSI'AH STABAT TAHUN PELAJARAN 2019/2020
}

\author{
${ }^{1}$ Silvia Ramadhani, ${ }^{2}$ Sri Zulhayana \\ ${ }^{1}$ Mahasiswa STKIP Budidaya Binjai Pendidikan Matematika, ${ }^{2}$ Dosen STKIP Budidaya \\ 1(e-mail : silviaeamdhani@gmail.com ), ${ }^{2}$ (e-mail : sri_zet@yahoo.com)
}

\begin{abstract}
ABSTRAK
Adapun tujuan dalam penelitian ini adalah untuk mengetahui pengaruh model pembelajaran think talk write terhadap kemampuan komunikasi matematis pada materi persamaan linier tiga variabel oleh siswa kelas X SMK Swasta Napsi'ah Stabat tahun pelajaran 2019/2020. Populasi dalam penelitian ini adalah keseluruhan siswa kelas X SMK Swasta Napsi'ah Stabat yang berjumlah 64 siswa. Sedangkan sampel yang diambil dalam penelitian ini adalah siswa kelas X-1 dan X-2 yang masing-masing berjumlah 32 siswa, dimana siswa kelas X-1 sebagai kelas eksperimen dan siswa kelas X-2 sebagai kelas kontrol. Penelitian ini merupakan penelitian eksperimen semu, dimana dalam mengambil data digunakan observasi terhadap siswa yang menggunakan model pembelajaran think talk write dan dengan menggunakan metode konvensional. Dari hasil perhitungan di peroleh nilai thitung $=2,30$. jika dilihat dari ttabel dengan taraf signifikan $5 \%$ di dapat $t_{\text {tabel }}=2.03$. jadi nilai $t_{\text {hitung }}>t_{\text {tabel }}$ maka dapat di simpulkan bahwa Ho di tolak dan Ha di terima maka hipotesis yang di ajukan bernilai benar adalah : Terdapat pengaruh model pembelajaran think talk write terhadap kemampuan komunikasi matematis pada materi persamaan linier tiga variabel oleh siswa kelas $\mathrm{X}$ SMK Swasta Napsi'ah Stabat tahun pelajaran 2019/2020.
\end{abstract}

Kata Kunci : Model Pembelajaran Think Talk Write, Kemampuan Komunikasi Matematis

\section{PENDAHULUAN}

Matematika adalah pelajaran yang diajarkan pada tingkat Pendidikan Anak Usia Dini (PAUD) hingga Perguruan Tinggi. Ini menandaikan bahwa matematika merupakan pelajaran wajib yang harus dipelajari oleh setiap siswa/mahasiswa yang belajar. Matematika merupakan raja sekaligus pelayan bagi ilmu-ilmu lainnya. Berkembangnya teknologi informasi dan komunikasi sekarang ini tidak terlepas dari adanya campur tangan matematika. Sebagai contoh adalah penggunaan logika matematika sebagai dasar bahasa pemprograman, struktur data kecerdasan buatan, sistem digital, basis data, teori komputasi, rekayasa perangkat lunak, jaringan saraf tiruan dan lainnya yang mempergunakan logika secara intensif. Selain itu, ada pula penggunaan lain dari matematika terhadap perkembangan teknologi, yaitu penggunaan algoritma untuk menghemat ukuran file serta dalam pemprograman komputer, penggunaan segitiga pascal dalam program turbo pascal, dan lain sebagainya. Masih banyak lagi sumbangan matematika dalam perkembangan teknologi yang merupakan dasar ilmu komputer. Menurut (Oktaviana, 2009:2) "Matematika adalah salah satu pelajaran yang sangat erat kaitannya dengan kehidupan sehari-hari, matematika perlu dipahami dengan baik oleh siswa". Namun kenyataannya hingga kini, masih saja siswa banyak yang mengalami kesulitan dalam mempelajari matematika. Sering dijumpai siswa yang kurang berminat dalam mempelajari matematika. Masalah yang sering dijumpai adalah siswa merasa bahwa pelajaran matematika tidak ada gunanya dalam 
kehidupan sehari-hari. Matematika diakui penting tetapi sulit dipelajari, maka tidak jarang murid yang awalnya menyenangi matematika, beberapa bulan kemudian sikapnya menjadi tidak acuh karena merasakan situasi belajar yang menjemukan.

Berdasarkan hasil wawancara dengan guru matematika di SMK Swasta Napsi'ah Stabat diketahui bahwa siswa kurang berminat terhadap matematika, hasil belajar masih rendah, keaktifan siswa dalam belajar masih rendah dan kemampuan siswa dalam mengkomunikasikan soal matematika masih rendah. Lebih lanjut dikatakan bahwa guru menerapkan berbagai variasi dalam mengajar.Lebih lanjut dikatakan bahwa kemampuan siswa dalam memahami konsep perbandingan. Oleh karena itu, kemampuan komunikasi matematis siswa perlu mendapat perhatian. (Noraini, 2005:7) menyatakan bahwa "Secara umum kemampuan komunikasi matematis adalah kemampuan dalam membaca, menafsir, dan menginterpretasi grafik, dan menggunakan konsep matematika yang benardalam menyampaikan argument secara lisan dan tulisan". Hal senada disampaikan oleh (Hamalik, 2008:186) komunikasi dapat terjadi dalam satu arah, yaitu dari penyampai pesan kepada penerima pesan. Salah satu penyebab rendahnya kemampuan komunikasi matematis siswa adalah model pembelajaran yang biasa diterapkan guru, yaitu model pembelajaran konvensional. Model pembelajaran konvensional membatasi keaktifan siswa dalampembelajaran, sehingga siswa tidak dapat mengembangkan kemampuan komunikasi matematis yang dimilikinya secara optimal. Upaya yang dapat dilakukan untuk mengembangkan kemampuan komunikasi matematis siswa adalah menerapkan model pembelajaran yang tidak membatasi keaktifan siswa dan didominasi oleh guru.

Menurut (Trianto, 2009:22) bahwa "Model pembelajaran mengacu pada pendekatan pembelajaran yang akan digunakan termasuk didalamnya tujuan-tujuan pengajaran, tahap-tahap dalam kegiatan pembelajaran, lingkungan pelajaran dan mengelolaan kelas".

Sedangkan menurut (Suherman, 2001:34) menyatakan: "Fungsi model pembelajaran adalah pedoman bagi perancang pengajaran dan para guru dalam merencanakan dan melaksanakan pembelajaran".

Suatu model pembelajaran yang diharapkan dapat menumbuhkembangkan kemampuan pemahaman dan komunikasi matematik siswa adalah model Think Talk Write (Martinis, dkk, 2008:85). Salah satu model pembelajaran yang dapat digunakan adalah model pembelajaran kooperatif tipe Think Talk Write (TTW) menyatakan bahwa SMK Swasta Napsi'ah Stabat pembelajaran kooperatif mengarahkan siswa untuk aktif dan pembelajaran tidak berpusat pada guru. Pembelajaran kooperatif melibatkan kelompok kecil yang terdiri dari 4-5 siswa dengan kemampuan yang berbeda. (Yamin, dkk, 2008: 90) menyatakan bahwa "Model pembelajaran tipe TTW terdiri dari tiga tahap. Tahap think mengarahkan siswa untuk berpikir dan membuat catatan kecil mengenai masalah dan solusi dari LKS. Tahap talk mengarahkan siswa untuk aktif berbicara dan berdiskusi bersama kelompok untuk membahas LKS. Tahap write mengarahkan siswa untuk mengkontruksi kesimpulan.

Berdasarkan uraian latar belakang masalah diatas, maka penelitian ini berjudul: "Pengaruh Model Pembelajaran Think Talk Write Terhadap Kemampuan Komunikasi Matematis Pada Materi Persamaan Linier Tiga Variabel Oleh Siswa Kelas X SMK Swasta Napsi'ah Stabat Tahun Pelajaran 2019/2020”.

\section{METODOLOGI PENELITIAN}

Penelitian ini akan dilaksanakan pada SMK Swasta Napsi'ah Stabat. Adapun waktu pelaksanaan penelitian ini akan dilaksanakan pada semester ganjil tahun pelajaran 2019/2020.

Populasi dan sampel penelitian ini adalah siswa yang duduk di kelas X SMK Swasta Napsi'ah Stabat Tahun Pelajaran 2019/2020 sebanyak 64 orang yang terdiri dari dua kelas. Jenis penelitian kuantitatif dengan metode penelitian eksperimen semu (quasi experimental). Variabel dalam penelitian ini yaitu Variabel bebas dalam penelitian ini 
adalah model pembelajaran Think Talk Write dan variabel terikat dalam penelitian ini adalah kemampuan komunikasi matematis. Alat pengumpulan data yaitu tes.

\section{III.HASIL PENELITIAN DAN PEMBAHASAN}

Dalam penelitian ini, data yang dideskripsikan peneliti meliputi data kemampuan komunikasi matematis pada materi persamaan linier tiga variabel oleh siswa kelas X SMK Swasta Napsi'ah Stabat tahun pelajaran 2019/2020. Penelitian ini menggunakan jenis penelitian eksperimen semu (quasi eksperimental) dengan desain "Randomized control group pretest-pascatest design" yakni menempatkan sampel penelitian ke dalam dua kelompok (kelas) yang dibedakan menjadi kategori kelas eksperimen dan kelas kontrol. Tujuan utama dalam penelitian ini adalah untuk mengetahui kemampuan komunikasi matematis pada materi persamaan linier tiga variabel oleh siswa kelas X SMK Swasta Napsi'ah Stabat tahun pelajaran 2019/2020 pada kelas eksperimen dan metode konvensional pada siswa kelas kontrol. Hasil penelitian kemampuan pemahaman konsep meliputi: deskripsi kemampuan pemahaman konsep, uji normalitas data, uji homogenitas data dan analisis uji hipotesis.

\section{A. Deskripsi Hasil Penelitian}

Penelitian merupakan penelitian eksperimen semu yang melibatkan dua kelas yang diberi perlakukan yang berbeda, yaitu kelas eksperimen yang diberikan perlakukan dengan menggunakan model pembelajaran think talk write dan kelas kontrol yang diberi perlakukan menggunakan metode konvensional. Data penelitian yang diperoleh dari pretest dan postest yaitu tes kemampuan komunikasi matematis siswa. Jumlah siswa pada kelas eksperimen dan kelas kontrol masing-masing berjumlah 32 siswa.

\section{Data Pretes}

Sebelum materi diajarkan atau sebelum adanya perlakuan pada tiap kelas,terlebih dahulu siswa diberi pretes untuk mengetaui kemampuan awal siswa teradap materi yang diteliti pada kelas eksperimen dan kelas kontrol. Adapun rangkuman nilai pretes dari kelas eksperimen dan kelas kontrol disajikan pada tabel berikut :

Tabel 1. Rangkuman Hasil Data Pretes Kelas Eksperimen dan Kelas Kontrol

\begin{tabular}{cccccccccc}
\hline \multicolumn{4}{c}{ Kelas Kontrol } & \multicolumn{5}{c}{ Kelas Eksperimen } \\
\hline $\boldsymbol{X} \boldsymbol{i}$ & $\boldsymbol{F}$ & $\overline{\boldsymbol{X}}$ & $\mathbf{S}$ & $\boldsymbol{S}^{\mathbf{2}}$ & $\boldsymbol{X} \boldsymbol{i}$ & $\boldsymbol{F}$ & $\overline{\boldsymbol{X}}$ & $\mathbf{S}$ & $\boldsymbol{S}^{\mathbf{2}}$ \\
\hline 25 & 2 & & & & 40 & 4 & & & \\
30 & 11 & & & & 45 & 5 & & & \\
35 & 5 & & & & 50 & 7 & & \\
40 & 7 & & & & 55 & 4 & & \\
45 & 2 & 35,2 & 7,4 & 54,76 & 60 & 6 & 52,7 & 8,2 & 67,24 \\
50 & 1 & & & & 65 & 3 & & & \\
55 & 3 & & & & 70 & 3 & & \\
$\Sigma$ & 32 & & & & $\Sigma$ & 32 & & \\
\hline
\end{tabular}

Pada tabel diatas menunjukkan bahwa nilai rata-rata pretes yang diperoleh di kelas eksperimen adalah 52,7. Jika dihitung persentasenya maka terdapat 16 orang $(50 \%)$ dibawah rata-rata dan 16 orang $(50 \%)$ diatas rata-rata.

Selain nilai rata-rata pretes kelas eksperimen tabel 1. memberikan informasi besar varians dan standar deviasi di kelas eksperimen masing-masing

adalah 67,24 dan 8,2. Jumlah keseluruhan nilai pretest siswa yang berjumlah 32 orang di kelas eksperimen sebesar 1580 .

Tabel 1. menunjukkan nilai rata-rata pretest yang diperoleh di kelas kontrol adalah 35,2 . Jika dihitung maka terdapat 19 orang $(59,4 \%)$ dibawah rata-rata dan 13 orang $(40,6 \%)$ diatas rata-rata. Selain nilai rata-rata pretest kelas kontrol tabel 4.1 memberikan informasi besar varians dan standar deviasi di kelas eksperimen masing-masing adalah 54,76 dan 7,4 . Jumlah keseluruhan nilai pretest siswa yang berjumlah 32 orang di kelas kontrol sebesar 1055. 


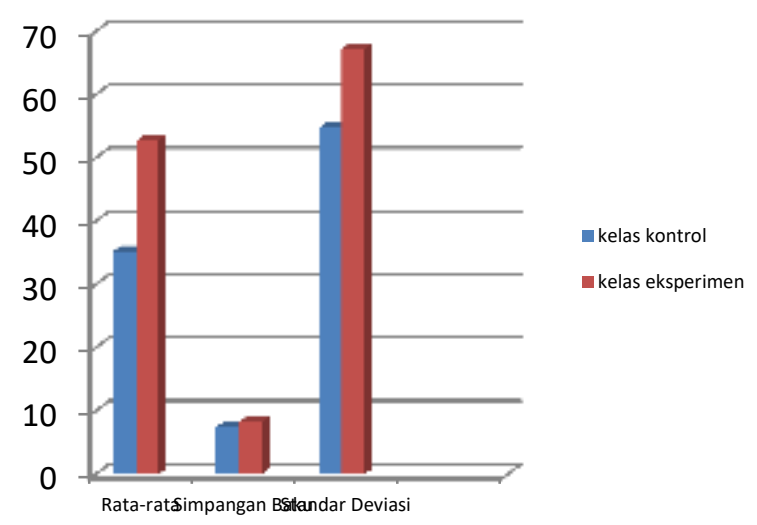

Gambar 1. Perbedaan Nilai Rata-Rata, Simpangan Baku dan Standar Deviasi Pretest Kemampuan Komunikasi Matematis Kelas Eksperimen dan Kelas Kontrol

\section{Data Postest}

Setelah diberikan pretest pada kedua kelas maka penelitian dilanjutkan dengan memberikan perlakuan yang berbeda. Pada kelas eksperimen diterapkan model pembelajaran think talk write yang dilakukan peneliti, sedangkan pada kelas kontrol diterapkan metode konvensional yang dilakukan guru matematika. Dikedua kelas kegiatan pembelajaran dilakukan sebanyak dua kali pertemuan. Setelah diberi perlakuan, kedua kelas diatur sedemikian rupa agar berdekatan,untuk menghindari kebocoran atau kecurangan yang mungkin saja terjadi. Saat pelaksanaan postest, suasana kelas cukup terkendali. Adapun rangkuman hasil nilai postest yang diperoleh siswa kelas eksperimen dan siswa kelas kontrol yang disajikan pada tabel berikut :

Tabel 2. Rangkuman Hasil Data Postest Kelas Eksperimen dan Kelas Kontrol

\begin{tabular}{|c|c|c|c|c|c|c|c|c|}
\hline \multicolumn{4}{|c|}{ Kelas Kontrol } & \multicolumn{5}{|c|}{ Kelas Eksperimen } \\
\hline$X i F$ & $\overline{\bar{X}}$ & $\mathbf{S}$ & $S^{2}$ & $\overline{X i}$ & $\bar{F}$ & $\overline{\bar{X}}$ & $\mathbf{S}$ & $S^{2}$ \\
\hline 353 & & & & 65 & 2 & & & \\
\hline 402 & & & & 70 & 2 & & & \\
\hline 457 & & & & 75 & 4 & & & \\
\hline 5010 & & & & 80 & 5 & & & \\
\hline 552 & 49,7 & 6,5 & 73,96 & 85 & 4 & 83,3 & 8,3 & 106,1 \\
\hline 604 & & & & 90 & 8 & & & \\
\hline 651 & & & & 95 & 2 & & & \\
\hline 703 & & & & 100 & 5 & & & \\
\hline$\Sigma 32$ & & & & $\Sigma$ & 32 & & & \\
\hline
\end{tabular}

Pada tabel 2. menunjukkan bahwa nilai rata-rata postest yang diperoleh di kelas eksperimen adalah 83,3. Jika dihitung persentasenya maka terdapat 11 orang $(34,4 \%)$ dibawah rata-rata dan 21 orang $(65,6 \%)$ diatas rata-rata.

Selain nilai rata-rata postest kelas eksperimen tabel 2. memberi informasi besar varians dan standar deviasi di kelas eksperimen masing-masing adalah 106,1 dan 8,3. Jumlah keseluruhan nilai pretest yang berjumlah 32 orang di kelas eksperimen sebesar 2666.

Tabel 2. menunjukkan nilai rata-rata postest yang diperoleh di kelas kontrol adalah 49,7. Jika dihitung maka terdapat 12 orang $(37,5 \%)$ dibawah rataan dan 20 orang $(62,5 \%)$ diatas rata-rata. Selain nilai rata-rata postest kelas kontrol tabel 2. memberikan informasi besar varians dan standar deviasi di kelas kontrol masing-masing adalah 73,96 dan 6,5.

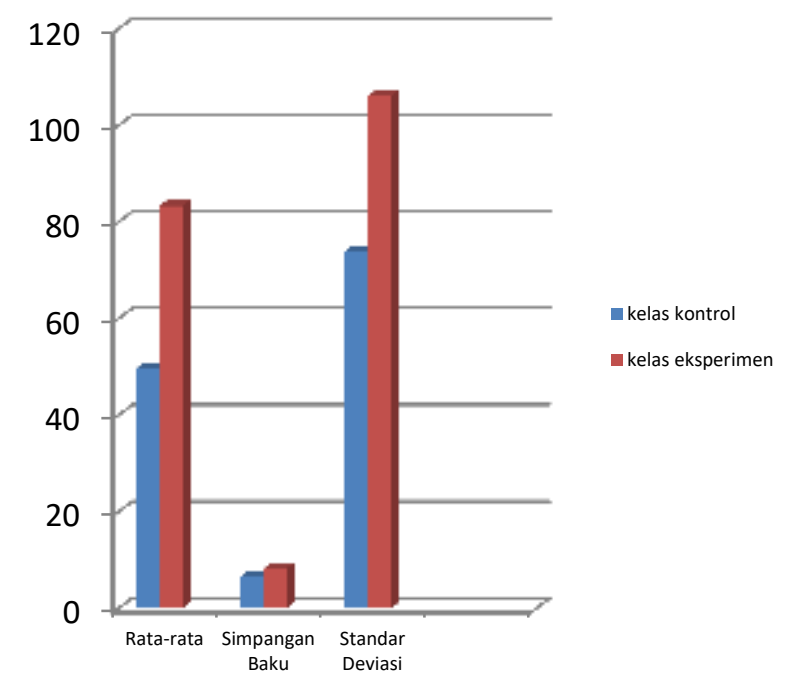

Gambar 2. Perbedaan Nilai Rata-Rata, Simpangan Baku dan Standar Deviasi Postest Kemampuan Komunikasi Matematis Kelas Eksperimen dan Kelas Kontrol

\section{B. Analisis Data Hasil Penelitian}

Analisis data hasil penelitian yang berupa tes kemampuan pemahaman konsep siswa dilakukan untuk membuktikan hipotesis penelitian yang telah diajukan, yaitu rata-rata kemampuan komunikasi matematis siswa yang diajar dengan menggunakan model 
signifikan 5\% db sebesar 2,03 yang dapat dilihat pada tabel berikut:

Tabel 5. Uji t Statistik

\begin{tabular}{ccc}
\hline $\begin{array}{c}\mathbf{t}_{\text {hitung }} \\
\boldsymbol{\alpha}=\mathbf{0 , 0 5}\end{array}$ & $\begin{array}{c}\mathbf{t}_{\text {tabel }} \\
\boldsymbol{\alpha}=\mathbf{0 , 0 5}\end{array}$ & Kesimpulan \\
\hline 2,3 & 2,03 & Tolak Ho \\
\hline
\end{tabular}

Berdasarkan tabel di atas diperoleh nilai $t_{\text {hitung }}=2,30$. jika dilihat dari $t_{\text {tabel }}$ dengan taraf signifikan $5 \%$ di dapat $t_{\text {tabel }}=2.03$. jadi nilai $t_{\text {hitung }}>t_{\text {tabel }}$ maka dapat di simpulkan bahwa Ho di tolak dan $\mathrm{Ha}$ di terima maka hipotesis yang di ajukan bernilai benar adalah : Terdapat pengaruh model pembelajaran think talk write terhadap kemampuan komunikasi matematis pada materi persamaan linier tiga variabel oleh siswa kelas X SMK Swasta Napsi'ah Stabat tahun pelajaran 2019/2020.

\section{Pembahasan Hasil Penelitian}

Pada bagian ini akan diuraikan deskriptif hasil penelitian dan faktor pembelajaran serta keterbatasan peneliti dalam melakukan penelitian.

Berdasarkan hasil yang diperoleh data kelas eksperimen yang mempunyai nilai ratarata pretes sebesar 52,7, rata-rata postes sebesar 83,3. Sedangkan untuk kelas kontrol memperolah rata-rata pretest sebesar 35,2, ratarata postes sebesar 49,7. Hal ini menunjukan bahwa kemapuan komunikasi matematis siswa kelas eksperimen yang diajarkan dengan menggunakan model pembelajaran think talk writelebih tinggi dibandingkan dengan rata-rata kemampuan komunikasi matematis kelompok kontrol yang diajarkan dengan menggunakan pembelajaran konvensional.

Kemampuan komunikasi matematis tersebut sangat dipengaruhi oleh kegiatan pembelajaran yang diterapkan dimasingmasing kelas. Pada kelas eskperimen yang menggunakan model pembelajaran think talk write, guru melakukan demonstrasi untuk mengali konsep awal siswa, selanjutnya guru mengelompokkan siswa secarra berpasangan. Guru memberikan suatu masalah yang berkaitan degan materi yang dipelajari. Kemudian siswa saling bertukar pikir dalam menyelesaikan masalah dalam bentuk soal yang diberikan guru. Pada tahap inilah siswa melatih kemampuan komunikasi matematis yang selanjutnya diberikan kesempatan untuk memaparkann hasil yang mereka peroleh bersama teman kelompok masing-masing. Setelah guru dan siswa berdiskusi untuk menyimpulkan hasil awaban yang tepat. Kemudian bersama-sama menyimpulkan materi yang telah dipelajari.

Pada kelas kontrol diberikan pembelajaran konvensional yaitu pembelajaran yang sudah biasa dilakukan oleh guru di kelas dimana pembelajaran berusat pada guru, komunikasi satu arah dari guru kepada siswa. Metode pembelajaran konvensional menggunakan metode ceramah, penugasan dan demonstrasi serta materi pembelajaran lebih pada penguasaan konsep-konsep bukan kompetensi. Setelah kedua kelas diberikan perlakuan yang berbeda, diakhiri dengan pemberian postes untuk melihat kemampuan komunikasi matematissiswa. Pada penelitian ini pembelajaran dengan model pembelajaran think talk writeyang diterapkan pada kelas eksperimen berhasil meningkatkan kemampuan komunikasi matematis siswa jika dibandingkan dengan pembelajaran konvensioanl yang diberikan pada siswa kelas kontrol.

Berdasarkan temuan penelitian maka dapat dikatana bahwa terdapat pengaruh model pembelajaran think talk write terhadap kemapuan kemunikasi matematis siswa khususnya pada materi persamaan linier tiga variabel sangatlah baik digunakan.

\section{KESIMPULAN DAN SARAN}

\section{A. Kesimpulan}

Berdasarkan pembahasan hasil penelitian, dapat disimpulkan bahwa :

1. Dari hasil analisis data kelas kontrol diketahui bahwa nilai rata-rata yang 
diperoleh siswa pada pretes sebesar 35,2 dengan besar standar deviasi 7,4. Data postes berdistribusi normal dan jenis populasi variansi berjenis homogen. Sedangkan pada postes diperoleh nilai ratarata sebesar 49,7 dengan besar standar deviasi 6,5. Data pretes berdistribusi normal dan jenis populasi variansi berjenis homogen.

2. Dari hasil analisis data kelas eksperimen disimpulkan bahwa nilai rata-rata yang diperoleh siswa pada pretes sebesar 52,7 dengan besar standar deviasi 8,5. Data pretes berdistribusi normal dan jenis populasi variansi berjenis homogen. Sedangkan pada postes diperoleh nilai ratarata sebesar 83,3 dengan besar standar deviasi 8,3. Data pretes berdistribusi normal dan jenis populasi variansi berjenis homogeny

3. Dari hasil perhitungan di peroleh nilai $t_{\text {hitung }}$ $=2,30$. jika dilihat dari ttabel dengan taraf signifikan $5 \%$ di dapat $t_{\text {tabel }}=2.03$. jadi nilai $t_{\text {hitung }}>t_{\text {tabel }}$ maka dapat di simpulkan bahwa Ho di tolak dan Ha di terima maka hipotesis yang di ajukan bernilai benar adalah : Terdapat pengaruh model pembelajaran think talk write terhadap kemampuan komunikasi matematis pada materi persamaan linier tiga variabel oleh siswa kelas X SMK Swasta Napsi'ah Stabat tahun pelajaran 2019/2020.

\section{B. Saran}

Adapun saran yang diberikan dalam penelitian ini adalah:

1. Bagi guru yang menggunakan model pembelajaran ini hendaknya mempersiapkan bahan atau sarana yang akan digunakan.

2. Pembelajaran dengan model pembelajaran think talk write dapat memberikan kontribusi yang positif bagi peningkatan hasil belajar siswa.

3. Bagi siswa-siswa agar lebih aktif dan berani dalam menyampaikan pendapat dan percaya diri dalam mengambil suatu pilihan dalam pelajaran matematika.

4. Bagi peneliti, kiranya hasilpenelitianini dapat menjadi informasi yang bergunan untuk dapat digunakan penelitan yang jenisnya sama.

\section{DAFTAR PUSTAKA}

Hamalik, Oemar, Perencanaan Pengajaran Berdasarkan Pendekatan Sistem, Jakarta: Bumi Aksara, 2008.

Idris, Noraini. Pedagogi dalam Pendidikan Matematik. Kuala Lumpur: Lohprint Sdn. Bhn, 2005.

Martinis Yamin dan Ansari. Taktik Membangun Kemampuan Individual Siswa. Jakarta: Gaung Persada Press. 2008.

Oktaviana, Dwi. Pengaruh Penerapan Model Pembelajaran Kooperatif Tipe STAD Berbantuan LKS Terhadap Hasil Belajar dan Aktivitas Belajar Siswa Pada Materi Trigonometri di Kelas X SMA Negeri 4 Pontianak. Pontianak : Jurnal IKIP-PGRI Pontianak. 2009. Vol 4 No. 2 ISSN: 1502-1726.

Suherman, Evaluasi Proses dan Hasil Belajar Matematika.Yogyakarta. :Penerbit Andi Offest : 2001.

Trianto, Mendesain Model Pembelajaran Inovatif-Progresif Konsep, Landasan dan Implementasinya Pada Kurikulum Tingkat Satuan Pendidikan (KTSP), Jakarta: Kencana Prenada Media Group 2009. 
Yamin dan Basun. Taktik Mengembangkan

Kemampuan Individual. Jakarta: Gaung

Persada Press. 2008. 